\title{
Representasi Gender pada Seni Lukis
}

\section{Kreativitas Anak}

\author{
Muhammad Surya Gumilang \\ Universitas Padjadjaran
}

\begin{abstract}
Creative children paintings are not only meant as children's freedom of expressing their creativity in processing shapes and media. Moreover, the paintings can be creativity to read gender representation. Those paintings can read perfect gender representation. In addition children paintings can be seen by how representation of gender structures is in the object of children paintings, chosen color, idea that is expressed by the children. Therefore, seeing the creative children paintings will be seen how close the gender structures is in the paintings. This research used qualitative method with semiotic analysis approach. Result of the research shows that creative children paintings are read by three components of object meaning procedure, color, and idea, each phase of children growth can explain how gender is reflected in discourse representation.
\end{abstract}

Keywords: gender, painting, creativity, children.

\section{PENDAHULUAN}

Memahami gender pada kacamata anakanak tentunya akan berbeda jika dilihat dari kacamata orang dewasa dan dari sudut pandang yang lain. Lukisan anak tidak begitu saja hadir, pasti ada pengaruh dari lingkungan sekitarnya. Apa yang dilukis anak merupakan transformasi kreativitas hasil dari yang dialami anak tersebut. Pada usia kecil anak-anak sudah diperkenalkan dengan jenis kelamin sehingga bisa membedakan mana laki-laki dan mana perempuan. Berangkat dari identitas seksual berlanjut pada identitas gender, pada tahap ini anak diperkenalkan kalau laki-laki bajunya bagaimana? dan perempuan bagaimana?, apa yang dimainkan laki-laki dan apa yang dimainkan perempuan?. Struktur normatifitas pada anak akan melekat dan membentuk ideologi. Dari pandangan inilah bagaimana karya lukis kreativitas anak tidak akan lepas dari struktur gender. Lukisan ini akan merepresentasikan identitas gender pada pelukisnya juga bagaimana bisa melekat 
pada objek yang dilukisnya. Berikut rangkaian pemikiran penelitian.

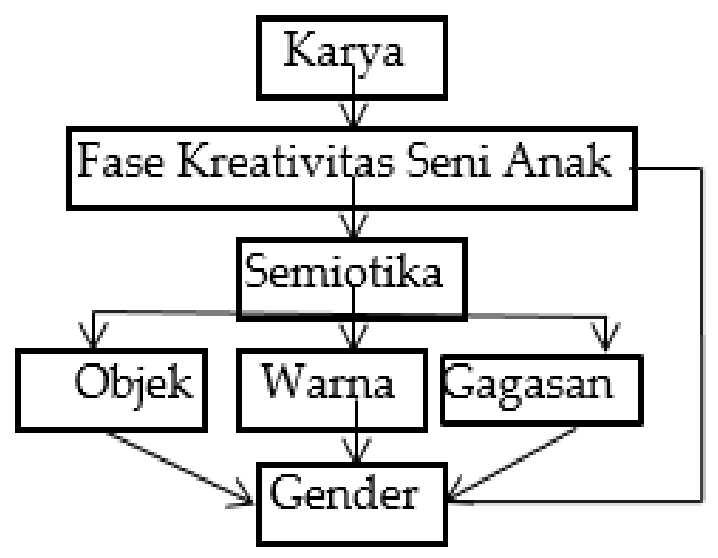

Gambar 1. Kerangka Pemikiran

\section{METODE PENELITIAN}

Metode yang digunakan dalam penelitian ini adalah metode kualitatif. Menurut (Stokes, 2006), penelitian kualitatif merupakan paradigma penelitian yang berkepentingan dengan makna dan penafsiran (Stokes, 2006). Artinya, penelitian kualitatif digunakan dengan maksud untuk menafsirkan fenomena yang terjadi dan dilakukan dengan melibatkan berbagai analisis. Metode ini pun seringkali dibedakan dengan metode kuantitatif yang lebih menekankan pada informasi-informasi numerik, kuantitas, maupun analisis statistik. Pisau pembedah analisis dilakukan dengan pendekatan semiotika (Roland Barthes, 1977). Barthes seperti dikutip (da Silva, 2005) menyatakan bahwa tanda-tanda dalam budaya bukanlah sesuatu yang polos murni (innocent), namun sebaliknya, tanda-tanda justru memiliki kaitan yang kompleks dengan reproduksi ideologi (da Silva, 2005:118). Termasuk dalam hal ini lukisan kreativitas anak dapat diposisikan sebagai sebuah tanda-tanda kebudayaan yang memiliki representasi muatan makna dan ideologi tertentu, yakni ideologi gender. Oleh karena itu, analisis semiotika digunakan guna menjelaskan bagaimana ideologi gender tersebut terlihat pada seni lukis kreativitas anak.

Objek analisis dipilih berdasarkan teknik purposive sampling yang menentukan pilihan sampel atau objek penelitian secara sengaja karena sampel tersebut dianggap memiliki ciri-ciri tertentu yang sesuai dengan tujuan penelitian. Meskipun begitu, faktor kesengajaan dalam memilih objek penelitian tidak semata-mata dilandaskan pada subjektivitas peneliti semata, tetapi didasarkan juga pada kerangka hipotesis yang muncul dari telaah teoritis.

\section{HASIL DAN PEMBAHASAN}

Berangkat dari memahami munculnya keilmuan gender tidak hanya membicarakan bagaimana peran seksualitas seseorang didalam kehidupan budaya saja, tapi ilmu gender ini sudah mengilhami penulis tentang bagaimana peran seksual seorang anak yang direpresentasikan pada hasil karya seni lukis yang dibuatnya. Melihat lukisan dari sudut gender, saya mengacu pada salah satu gagasan dalam pemikiran Judith Butler mengenai performativitas gender dan seks. Gender, 
bahkan seks, bagi Judith Butler merupakan "pertunjukan", bukan esensi, atau ekspansi dari seks yang ada pada tubuh.

Bagi Butler, gender adalah drag, atau seperti drag, yaitu bagaimana pertunjukan seorang ratu kecantikan untuk menguji dan membuktikan mereka telah menghasilkan femininitas yang sebenarnya. Dalam pertunjukan itu, para juri telah mengetes dan mengesahkan tinggi badan, kehalusan dan warna kulit, kegemulaian gerak, kelembutan suara.

Gender kita semua adalah "pertunjukan" atau hasil pertunjukan seperti itu, jadi bagaikan peran yang dimainkan dipanggung. Para jurinya adalah teman kita, orang tua kita, media dan sebagainya. Seperti yang diungkap oleh Judith Butler, maka disini performativitas itu juga akan hadir pada karya seni lukis, khususnya hasil kreativitas anak.

Gender seperti yang diungkap oleh Judith Alimi (2011), mengungkapkan bahwa gender bagi Butler bukan seseorang, tapi merupakan sesuatu yang dilakukan orang (gender is not something that one is, it is something one does) gender lebih merupakan doing dari pada being (an act... a "doing" rather than a "being"). Artinya, tidak ada esensi gender dibalik ekspresi gender; performativitas itulah yang membentuk apa yang dianggap sebagai esensi. "There is no gender identity behind the expressions of gender; that identity is performatively constituted by the very "expressions" that are said to be its results" (Alimi 2011). Oleh karena itu, gender adalah imitasi, tidak ada yang asli. Imitasi itulah yang telah menghasilkan apa yang dianggap asli itu sendiri. Butler (1990) menulis "Gender is a kind of imitation for which there is no original; in fact, it is a kind of imitation that produces the very notion of the original as an effect and consequence of the imitation itself. "Imitation and Gender Insubordination" in Inside/Out.

Kreativitas seni lukis yang dibuat oleh anak tidak sedikit merepresentasikan tentang gender, seperti lukisan keluarga, juga tokoh idolanya di televisi, sehingga hal tersebut bisa berkontribusi terkait pada bagaimana konstruksi gender yang ada pada lukisan anak. Gender pada lukisan anak yang bertema keluarga biasanya disimbolkan dengan beberapa bentuk visual seperti rumah, halaman, ayah, ibu dan anak seorang menjadi ilustrasi kreatif yang melukisnya itu sendiri. Dari lukisan tersebut anak tidak hanya berbicara soal keberadaan keluarga saja, tapi ada ruang pandangan lain mengapa anak tersebut melukis seolah keluarga pada lukisan tersebut bahagia, juga bagaimana anak tersebut melukis pakaian yang dipakaikan pada lukisan dirinya. Dengan menghadirkan tokoh idola, anak perempuan tersebut menghadirkan lukisan yang selayaknya banyak anak perempuan lain yang menggemari tokoh tersebut seperti tokoh princes. Begitu juga anak laki-laki yang merepresentasikan bahwa dia 
seorang laki-laki dengan melukiskan tokoh super hero, kendaraan mobil dan pesawat.

Lukisan merupakan media ekspresi bagi anak-anak, bahkan dapat dikatakan sebagai media komunikasi. Melukis dapat diartikan sebagai cara mentransfer apa yang dipikirkan ke dalam sebuah bentuk visual. Setiap anak menyukai kegiatan melukis, karena melukis bagi anak adalah bentuk komunikasi yang paling mengasikkan, namun kadang masih sangat sulit dipahami, dan bisa dipahami setelah anak mengungkapkan cerita tentang apa yang dia lukis.

Saputra (2004), mengungkapkan “Kaji Banding Bahasa Rupa Gambar Anak Usia Pra Sekolah (2-6 Tahun) Di Empat Kota : Jakarta, Bandung, Yogjakarta dan Surabaya" dikatakan bahwa "Setiap anak suka melukis, tidak peduli mereka berbakat atau tidak, ini merupakan anugerah Tuhan, agar anak dapat membina kemampuan untuk berfikir dan berkomunikasi (berfikir) dengan rupa. Anak-anak sudah berkomunikasi dengan bahasa rupa gambar sebelum ia bisa menulis. Berkomunikasi dengan gambar diperoleh setiap anak secara alami, maka mereka lebih menguasai berkomunikasi secara gambar dari pada tulisan, yang baru kemudian dipelajari. Menggambar bagi anak adalah sebuah media ekspresi terhadap apa yang ia pikirkan, rasakan, dan ketertarikannya dari kerjasama seluruh inderainderanya dan memperlihatkan kemampuan lingkungannya dalam ekspresi kreatif masing-masing. Karena kegiatan menggambar yang dimulai dengan aktivitas mencoret adalah hal yang mudah untuk dilakukan oleh setiap anak, maka mereka gemar melakukannya".

Penelitian Saputra (20014) tersebut bisa dijadikan salah satu tolak ukur bagaimana didalam seni lukis karya anak itu terdapat representasi gender. Karena diungkapkan tujuan anak melukis dengan tujuan orang dewasa itu jelas berbeda, anak akan lebih jujur dan melahirkan visual yang apa adanya didalam kehidupan dan imajinasi anak. Gender akan hadir dengan tidak dibuatbuat, sehingga dapat terkomunikasikan.

Dalam buku Ilmu Komunikasi Suatu Pengantar, (Mulyana, 2008:60-61) Dance, menemukan tiga dimensi konseptual penting yang mendasari definisi-definisi komunikasi:

a. Dimensi pertama adalah tingkat observasi (level of observation), atau derajat keabstrakannya. Definisi komunikasi sebagai "proses yang menghubungkan satu sama lain bagian-bagian terpisah dunia kehidupan", adalah terlalu umum.

b. Dimensi kedua adalah kesengajaan (Intentionality). Contoh ini dikemukakan oleh Gerald R. Miller (sumber), yakni Komunikasi sebagai "Situasisituasi yang memungkinkan suatu sumber mentransmisikan 
suatu pesan kepada seseorang penerima dengan disadari untuk mempengaruhi perilaku penerima".

c. Dimensi ketiga adalah penilaian normatif. Contoh ini dikemukakan oleh John B. Hoben, yang mengasumsikan bahwa "komunikasi adalah pertukaran verbal pikiran atau gagasan".

Dalam permasalahan representasi gender seni lukis kreativitas anak ini komunikasi lebih dekat pemahamannya dengan dimensi ketiga yang diungkapkan oleh John B. Hoben, karena dengan sangat sadar anak ingin mengkomunikasikan melalui bahasa visual.

Damajanti (2006) telah mengelompokan garis besar kreativitas menjadi dua kelompok, yaitu:

1. Teori yang mendasarkan pada inspirasi, aspek ketidaksadaran (unconscious). Disini kreativitas dipandang sebagai suatu peristiwa tak sadar yang tidak dapat diprediksi. Kreativitas dianggap berkorelasi dengan inspirasi atau ilham.

2. Teori yang mendasarkan pada kehendak atau kemauan sadar (conscious) yang kuat. Dalam teori ini kreativitas dianggap berdasar pada pola perilaku yang disadari, dapat dilatih atau direkayasa, dan dapat ditumbuhkan.
Dari begitu beragamnya pengertian kreatif, penulis melihat dalam buku Kreativitas dan Humanitas, Primadi Tabrani (2006) dimana beliau mendefinisikan sementara mengenai kata kreatif. Kemampuan kreatif manusia yang membantunya untuk dapat berbuat lebih dari kemungkinan rasional dari data dan pengetahuan yang dimilikinya.

Menurut pemahaman saya mengenai kreativitas, dapat saya pahami bahwa kreativitas itu bukan hanya hasil yang dapat dilihat dan diraba oleh setiap manusia, namun kreativitas dapat berupa proses yang bahkan tidak terlihat sama sekali. Dan secara sederhana diartikan sebagai cara manusia untuk memecahkan masalah dengan cara yang baru dan berani. Dalam bahasan ini kreativitas diharapkan dapat berperan sebagai faktor representasi seni lukis karya kreativitas anak, sehingga lukisan tersebut bisa terkomunikasikan secara gender.

Dari beberapa keterangan yang penulis temukan, dapat dipahami bahwa seni lukis adalah sebuah proses yang merepresentasikan sebuah ide dan gagasan dalam imajinasi atau fenomena ke dalam bentuk rupa seperti garis, warna, dan bentuk sehingga dengan itulah gender akan terlihat. Tahap perkembangan menurut Viktor Lowenfeld dan Lambert Brittain (1970) dalam: Creative and Mental Growth membagi periodisasi perkembangan 
seni rupa anak menjadi lima periodesasi perkembangan yaitu: Masa CorengMoreng (Scribbling Period) 2 - 4 Tahun, Masa Pra Bagan (Pre Schematic Period) 4 - 7 Tahun, Masa Bagan (Schematic Period) 7 - 9 Tahun, Masa Realisme Awal (Early Realism) 9-12 Tahun, Masa Naturalisme Semu 12 - 14 Tahun dan Periode Penentuan 14-17 Tahun.

\section{a. Masa Coreng-moreng (Scribbling Period) 2 - 4 Tahun}

Kesenangan membuat goresan pada anak-anak usia dua tahun bahkan sebelum dua tahun sejalan dengan perkembangan motorik tangan dan jarinya yang masih menggunakan motorik kasar. Hal ini dapat kita temukan anak yang melubangi atau melukai kertas yang digoresnya. Goresan-goresan yang dibuat anak usia 2-3 tahun belum menggambarkan suatu bentuk objek. Pada awalnya, coretan hanya mengikuti perkembangan gerak motorik. Biasanya tahap pertama hanya mampu menghasilkan goresan terbatas, dengan arah vertikal atau horizontal.

Hal ini tentunya berkaitan dengan kemampuan motorik anak yang masih mengunakan motorik kasar. Kemudian pada perkembangan berikutnya penggambaran garis mulai beragam dengan arah yang bervariasi pula. Selain itu mereka juga sudah mampu mambuat garis melingkar. Periode ini terbagi ke dalam tiga tahap, yaitu: 1) coretan tak beraturan, 2) coretan terkendali, dan 3) coretan bernama. Ciri gambar yang dihasilkan anak pada tahap coretan tak beraturan adalah bentuk gembar yang sembarang, mencoreng tanpa melihat ke kertas, belum dapat membuat coretan berupa lingkaran dan memiliki semangat yang tinggi coretan terkendali ditandai dengan kemampuan anak menemukan kendali visualnya terhadap coretan yang dibuatnya. Hal ini tercipta kerjasama antara koordinasi antara perkembangan visual dengan perkembangan motorik. Hal ini terbukti dengan adanya pengulangan coretan garis baik yang horizontal ,vertikal, lengkung, bahkan lingkaran.
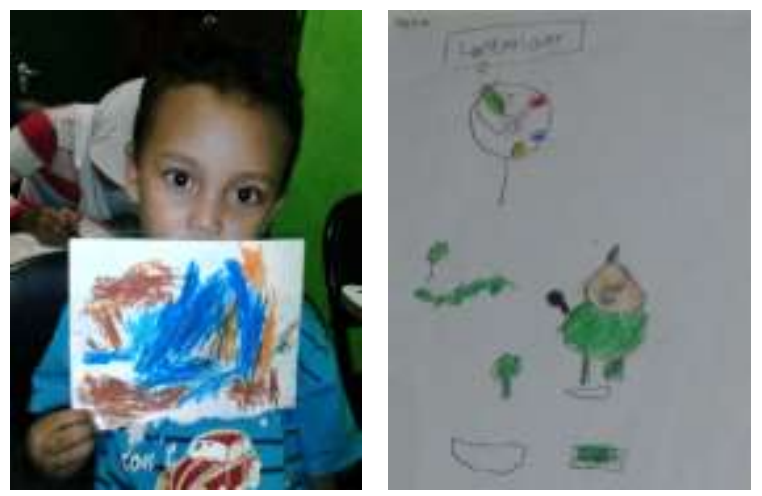

Gambar 2. Gambar Coretan Anak (sumber: Dokumentasi Penulis)

Pada foto di atas terlihat ada seni lukis kreativitas anak laki-laki dan satunya seni lukis kreativitas anak perempuan pada usia yang tidak jauh antara 2-3 tahun. Pada karya tersebut terdapat perbedaan yang merepresentasikan betapa struktur gender melekat pada seni lukis kreativitas anak. Pada seni lukis kreastivitas anak laki-laki lebih menggunakan warna yang pekat tajam dan gelap, sedangkan karya perempuan lebih memilih warna yang muda dan 
cerah. Objek yang dipilih anak perempuan identik dengan bunga, sedangkan anak laki-laki lebih memilih objek gunung yang menjulang tanpa ada bunga.

Coretan bernama merupakan tahap akhir masa mencoret-coret. Biasanya terjadi menjelang usia 3-4 tahun, sejalan dengan perkembangan bahasanya anak mulai mengendalikan goresannya bahkan telah memberinya nama, misalnya, "rumah", "mobil", "kuda". Hal ini dapat digunakan oleh orang tua atau guru pada jenjang pendidikan usia dini (TK) dalam membangkitkan keberanian anak untuk mengemukakan kata-kata tertentu atau pendapat tertentu berdasarkan hal yang digambarkannya. Anak-anak memiliki jiwa bebas dan ceria. Mereka sangat menyenangi warna-warna yang cerah misalnya dari crayon. Kesenangan menggunakan warna biasanya setelah ia bisa memberikan judul terhadap karya yang dibuatnya.

Penggunaan warna pada masa ini lebih menekankan pada penguasaan teknik penempatan warna berdasarkan kepraktisan penempatan dibandingkan dengan kepentingan aspek emosi. Pada masa mencoret, bila anak difasilitasi oleh orang tua maka akan memiliki peluang untuk melakukan kreasi dalam hal garis dan bentuk, mengembangkan koordinasi gerak, dan mulai menyadari ada hubungan gambar dengan lingkungannnya. Hal yang paling penting yang harus dilakukan oleh orang tua dan guru pada masa ini adalah dengan memberi perhatian terhadap karya yang sedang dibuat anak sehingga tercipta kemampuan komunikasi anak dengan orang dewasa secara melalui bahasa visual.

Meski dalam periode ini gender tidak terlihat dalam bentuk, tapi pemilihan warna dan tekanan garis yang ditunjukan anak saat melukis antara anak laki-laki dan anak perempuan akan menghasilkan tekanan garis dan pemilihan warna yang akan berbeda. Anak laki-laki akan lebih gagah dalam menarik garis dan lebih menggunakan warna tajam seperti hitam, biru, merah, hijau, meskipun ada juga anak laki yang tertarik warna pastel.

\section{b. Masa Pra-Bagan (Pre-Schematic Period) 4 - 7 Tahun}

Usia anak pada tahap ini bisanya berada pada jenjang pendidikan TK dan SD kelas awal. Kecenderungan umum pada tahap ini, objek yang digambarkan anak biasanya berupa gambar kepala-berkaki. Sebuah lingkaran yang menggambarkan kepala kemudian pada bagian bawahnya ada dua garis sebagai pengganti kedua kaki.

Ciri-ciri yang menarik lainnya pada tahap ini yaitu menggunakan bentukbentuk dasar geometris untuk memberi kesan objek dari dunia sekitarnya. Koordinasi tangan lebih berkembang. Aspek warna belum ada hubungan tertentu dengan objek, orang bisa saja 
berwarna biru, merah, coklat atau warna lain yang disenanginya.

Penempatan dan ukuran objek bersifat subjektif, didasarkan kepada kepentingannya. Jika objek gambar lebih dikenalinya seperti ayah dan ibu, maka gambar dibuat lebih besar dari yang lainnya. Hal ini disebut dengan "perspektif batin". Penempatan objek dan penguasan ruang belum dikuasai anak pada usia ini.

\section{c. Masa Bagan (Schematic Period) 7 - 9} Tahun

Konsep bentuk mulai tampak lebih jelas. Anak cenderung mengulang bentuk. Gambar masih tetap berkesan datar dan berputar atau rebah (tampak pada penggambaran pohon di kiri kanan jalan yang dibuat tegak lurus dengan badan jalan, bagian kiri rebah ke kiri, bagian kanan rebah ke kanan). Pada perkembangan selanjutnya kesadaran ruang muncul dengan dibuatnya garis pijak (base line).

Penafsiran ruang bersifat subjektif, tampak pada gambar "tembus pandang". Gejala ini disebut dengan idioplastis (gambar terawang, tembus pandang). Misalnya gambar sebuah rumah yang seolah-olah terbuat dari kaca bening, hingga seluruh isi di dalam rumah kelihatan dengan jelas. Kenyataan di atas diperkuat oleh pandangan Max Verworm, bahwa anak menggambar benda-benda menurut apa yang dilihatnya. Hasil karya anak-anak itu disebutnya gambar fisioplastik.
Anak yang belum berumur 8 tahun belum mampu menggambar apa yang dilihatnya tetapi mereka menggambar menurut apa yang sedang dipikirkannya. Hasil karya mereka itu disebut gambar ideoplastik.

Pada masa ini juga, kadang-kadang dalam satu bidang gambar dilukiskan berbagai peristiwa yang berlainan waktu. Hal ini dalam tinjauan budaya dinamakan continous narrative, anak sudah bisa memahami ruang dan waktu. Objek gambar yang dilukiskan banyak dan berulang menggambarkan sedang dilakukan.

Dalam masa pra bagan dan masa bagan, normatifitas sudah masuk kedalam ideologi anak, seperti gambar di dalam rumah ada keluarga yang didalamnya terdapat ayah dan ibu ada anak yang menggunakan penampilan pakaian sesuai dengan seksualitasnya seolah ingin menunjukan aku adalah laki-laki atau aku adalah perempuan.

\section{d. Masa Realisme Awal (Early Realism) 9-12 Tahun}

Pada periode realisme awal, karya anak lebih menyerupai kenyataan. Kesadaran perspektif mulai muncul, namun berdasarkan penglihatan sendiri. Mereka menyatukan objek dalam lingkungan. Selain itu kesadaran untuk berkelompok dengan teman sebaya dialami pada masa ini. Perhatian kepada objek sudah mulai rinci. Namun demikian, dalam menggambarkan 
objek, proporsi (perbandingan ukuran) belum dikuasai sepenuhnya.

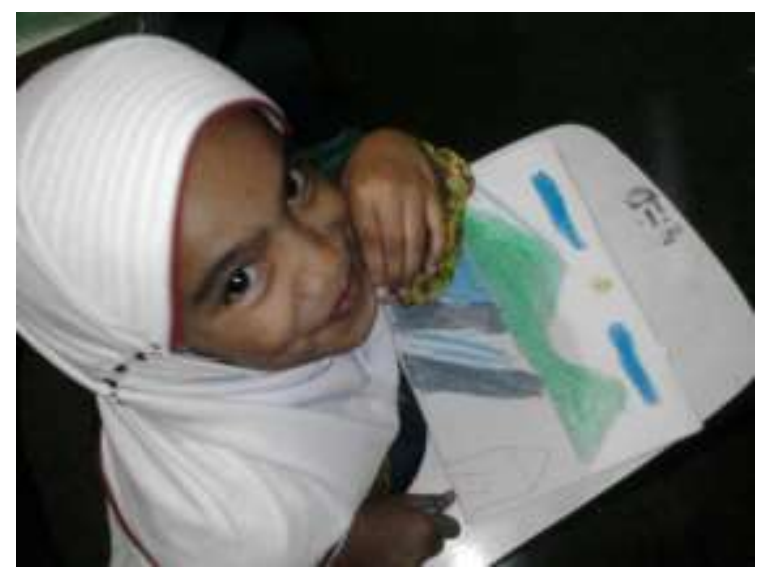

Gambar 3. Gambar Anak Periode Realisme Awal (sumber: Dokumentasi Penulis

Pemahaman warna sudah mulai disadari. Warna biru langit berbeda dengan biru air laut. Penguasan konsep ruang mulai dikenalnya sehingga letak objek tidak lagi bertumpu pada garis dasar, melainkan pada bidang dasar sehingga mulai ditemukan garis horizon. Selain dikenalnya warna dan ruang, penguasaan unsur desain seperti keseimbangan dan irama mulai dikenal pada periode ini. Ada perbedaan kesenangan umum, misalnya: anak lakilaki lebih senang menggambarkan kendaraan, sedangkan anak perempuan pada boneka atau bunga.

Semakin sadar akan warna maka anak akan semakin memperlihatkan peran seksualitasnya. Anak sudah mulai bersosialisasi dengan teman-temannya di masa ini, sehingga ideologi akan saling mempengaruhi dan ingin memperlihatkan antara peran femininitas dan maskulinitasnya.

\section{e. Masa Naturalisme Semu 12 - 14 Tahun}

Pada masa naturalisme semu, kemampuan berfikir abstrak serta kesadaran sosialnya makin berkembang. Perhatian kepada seni mulai kritis, bahkan terhadap karyanya sendiri. Pengamatan kepada objek lebih rinci. Tampak jelas perbedaan anak-anak bertipe haptic dengan tipe visual. Tipe visual memperlihatkan kesadaran rasa ruang, rasa jarak dan lingkungan, dengan fokus pada hal-hal yang menarik perhatiannya. Penguasaan rasa perbandingan (proporsi) dan gerak tubuh objek lebih meningkat.

Tipe haptic memperlihatkan tanggapan keruangan dan objek secara subjektif, lebih banyak menggunakan perasaannya. Gambar gaya kartun banyak digemari. Ada sesuatu yang unik pada masa ini, di mana pada satu sisi anak ekspresi kreatifnya sedang muncul sementara kemampuan intelektualnya berkembang dengan sangat pesatnya. Sebagai akibatnya, rasio anak seakan-akan menjadi penghambat dalam proses berkarya.

Contoh nya aka nada pertanyaan : Apakah gambar ini seperti kucing?. Sementara kemampuan menggambar kucing masih kurang. Akibatnya mereka malu kalau memperlihatkan karyanya kepada sesamanya. 


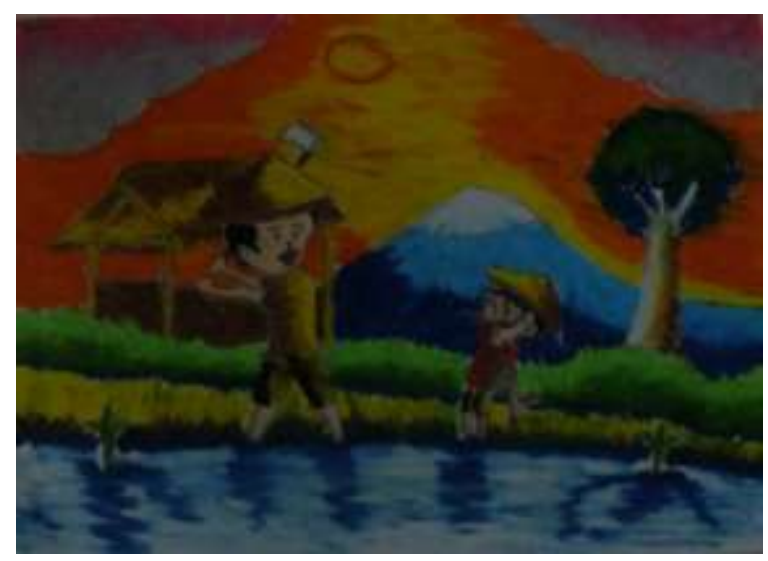

Gambar 4. Contoh Gambar pada Naturalisme Semu (sumber: Dokumentasi Penulis)

Terlihat pada gambar 4 pada masa naturalisme semu ini representasi gender akan terlihat jelas secara bentuk dan warna. Anak sudah bisa melukis secara detail bukan hanya secara visual saja, melainkan sudah melukiskan tentang apa saja yang ada pada dirinya dan yang ditemukan diluar dirinya. Pada seni lukis kreatifitas anak pada gambar diatas terlihat sangat jelas representasi gender. Terdapat objek seorang ayah yang sedang bekerja mencangkul, dan anak yang mengikuti apa yang dilakukan anaknya. Warna yang ditampilkan pun sangatlah jelas, lukisan itu mengambil suasana sore seakan seorang ayah harus bekerja keras sampai larut dan anak laki-laki harus mencontoh apa yang dilakukan ayahnya. Pada lukisan tersebut lukisan terdapat gradasi warna tetapi anak tidak berani menghadirkan objek bunga atau buah, seolah menegaskan identitas gender bahwa yang melukis ini seorang anak laki-laki.

\section{f. Periode Penentuan 14-17 Tahun}

Pada periode ini tumbuh kesadaran akan kemampuan diri. Perbedaan tipe individual makin tampak. Anak yang berbakat cenderung akan melanjutkan kegiatannya dengan rasa senang, tetapi yang merasa tidak berbakat akan meninggalkan kegiatan seni rupa, apalagi tanpa bimbingan. Dalam hal ini peranan guru banyak menentukan, terutama dalam meyakinkan bahwa keterlibatan manusia dengan seni akan berlangsung terus dalam kehidupan. Seni bukan urusan seniman saja, tetapi urusan semua orang dan siapa pun tak akan terhindar dari sentuhan seni dalam kehidupannya sehari-hari.

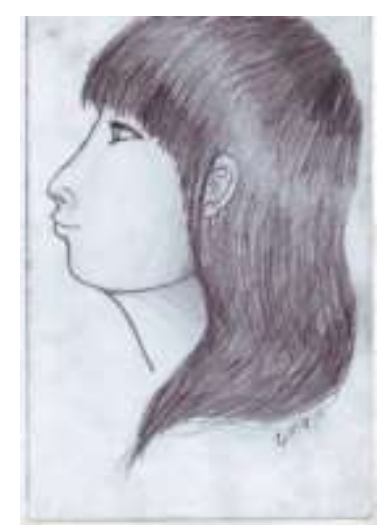

\section{Gambar 5. Contoh Gambar pada Periode Penentuan (sumber: Dokumentasi Penulis)}

Pada periode penentuan bukannya memperjelas representasi gender, justru gender akan terlihat semu, karena pada periode ini sudah ada pergeseran tujuan anak dalam melukis. Pergeseran tujuan melukis dan ideologi yang masuk pada anak tersebut jelas akan berpengaruh besar pada representasi gender mereka. 
Pada dasarnya ketika anak tersebut menguasai secara teknis melukis maka apapun bisa dilukisnya sesuai dengan kehendak individualnya ataupun gesekan dan permintaan dari luar dirinya, sehingga makna representasi gender-nya akan berbeda pula.

Pada akhirnya penulis memahami tentang konstruksi dan representasi gender pada seni lukis kreatifitas anak, lantas bagaimana mungkin bisa gender terlepas dari keilmuan seni rupa, khususnya seni lukis anak?. Sebab gender akan selalu hadir pada karya seni lukis dan begitu pula karya seni lukis akan merepresentasikan gender-nya. Bagaimana bisa kita membicarakan fase atau masa perkembangan seni rupa anak tanpa melihat gender pada karya anak tersebut?. Pada nyatanya anak memperlihatkan siapa dirinya hasil dari ideologi gender yang sudah tertanam pada anak tersebut.

\section{KESIMPULAN}

Pada bagian terakhir tulisan ini, ada dua hal penting yang ingin saya refleksikan, pertama bahwa seni lukis kreativitas anak bukan sekadar karya estetis yang berfungsi sebagai ekspresi anak semata. Tetapi merupakan sebuah ruang identitas yang memperlihatkan sebuah sistem budaya yang ditransformasikan oleh seorang anak. Kedua, dengan melihat seni lukis kreativitas anak, kita bisa melihat dan membuat penjelasan lebih lanjut bagaimana pandangan gender anak. Sehingga dalam konteks ini orang tua atau pendidik bisa memberi pandangan normatifitas dari semenjak anak dalam usia dini. Sehingga estetika karya seni tidak hanya mempersoalkan soal keindahan, tapi terefleksikan kedalam pandangan yang dihadapi dengan keseharian kita.

\section{DAFTAR PUSTAKA}

Alimi, Moh Yasir.

(2011), Judith Butler: Gender/Seks sebagai "Pertunjukan" dan Tawa Medusa. Jakarta Selatan: Komunitas Salihara.

Butler, Judith.

(1990), "Subjects of sex/gender/desire" in Gender trouble: feminism and the subversion of identity: Routledge.

Damajanti, Irma.

(2006), Pisikologi Seni. PT. Kiblat Buku Utama, Bandung.

Effendy, U. Onong.

(2008), Dinamika Komunikasi. Bandung: PT. Remaja Rosdakarya.

Lowenfeld, Victor \& Brittain, W. Lambert.

(1975), Creative and Mental Growth. Six Edition. New York: Macmillan Publishing Co., Inc.

Mulyana, Deddy.

(2008), Ilmu Komunikasi Suatu Pengantar. PT. Remaja Rosdakarya, Bandung.

Saputra, Yanty Hardi.

(2004), Kaji Banding Bahasa Rupa Gambar Anak Usia Pra Sekolah (2-6 Tahun) Di Empat Kota : Jakarta, Bandung, Yogjakarta dan Surabaya. Tesis Pascasarjana, Institut Teknologi Bandung. 
Stokes, J.

(2006), How To Do Media and Cultural Studies: Panduan untuk

Melaksanakan Penelitian dalam

Kajian Budaya dan Media.

Yogyakarta: Bentang.

Tabrani, Primadi.

(2006), Kreativitas dan Humanitas.

Yogyakarta dan Bandung:

Jalasutra. 